\title{
FAKE YOUR OWN DEATH: MOCK-SUICIDE AND THE END OF IDENTITY IN JEAN PAUL AND ŽIŽEK
}

\author{
William Coker
}

In the film Zizek!, the title-character reactivates the Romantic motif of mock-death (Scheintod), inducing a split in his identity. Toward the end of the film, Slavoj Žižek says in response to a question at a talk that he must kill off his clown persona in order to be taken seriously. Žižek chooses a spiral staircase as the setting for his mock-suicide because it is inside, protected from public view, and thus avoids the bad faith of a public spectacle that would "embarrass people and so forth"; yet by putting it all on film, he makes it a spectacle nonetheless. ${ }^{1}$ A common visual metaphor of dialectic, the spiral image renders Žižek's mock-suicide an uncanny comic allegory of his thought. ${ }^{2}$ In the end we see Žižek lying face-down on the marble floor, his comic self supposedly dead, in a comical impersonation of a corpse. ${ }^{3}$

Though Žižek proposes to strip off the layer of comic semblance accompanying his work to lay bare its serious core, the attempt fails comically, signaling that the comic semblance is integral to the communication of the serious core. Here and elsewhere, Žižek's performances manifest an indissoluble unity of seriousness and play: indissoluble, yet deeply fractured. Throughout his oeuvre, scurrilous jokes and provocations move the argument along, frequently providing the transition between serious philosophical claims. There is hardly a philosophical argument in Žižek without its joke version.

R\&L 5o.3 (Autumn 20I8) 
It is not hard to discern what philosophical problem resonates in the joke of Žižek's mock-suicide. In The Puppet and the Dwarf, Žižek questions "the subjective status of Christ: when he was dying on the Cross, did he know about his resurrection to come? If he did then it was all a game..." The question resurfaces repeatedly in his work: was the crucifixion, the pivotal moment in the history of humanity's relationship to God, in some sense staged, a mise-en-scène? Though Žižek is willing to sacrifice divine omniscience in order to answer it in the negative, this question returns on the level of Žižek's own practice. A professed atheist who sees "the Christian experience" as the only conduit to dialectical materialism cannot easily wave away the suspicion that his commitment to Christianity is performative, a game played for another purpose. ${ }^{5}$ Yet if we take Žižek at his word, that purpose cannot be conceived without the performance: "the fiasco of God is still the fiasco of God."'6

Theology may be the puppet in the mechanical Turk of Žižek's argumentation, and historical materialism the hidden dwarf, ${ }^{7}$ yet Žižek intimates that the dwarf cannot function without the puppet. Christianity's subversive potential is crucial to the prevention of a dead end in which twentieth-century historical materialism found itself and which appears emblematically in the figure of Stalin. To Žižek, the spectacle of God's death on the cross spells the end of the omniscient "big Other" whose gaze fixed all human action in the economy of sin and law. ${ }^{8}$ God's death grants believers the freedom to reconstitute the symbolic order of faith through their own activity, without a fetish that would enable them to pass responsibility for their actions onto a higher power.

This subversive scheme stands in stark contrast to "really existing Christianity," in which the risen Christ appears as a fetish enabling Christians to position themselves as agents of the will of an absent God, and also to Stalinist Communism, whose cadres commit themselves not to each other but to the "objective" laws of History, encouraged by the fetish of the leader. ${ }^{10}$ Though Žižek's is an atheist reading of Christianity, it is accessible only once one has identified Christ as God. Likewise, it is only by thinking through the properly subversive Christian experience that Žižek articulates how historical materialism has gone off the rails. Insofar as Žižek distinguishes his work's Christian semblance from its historical materialist core, there is no indication that core and semblance can be separated.

Žižek is not the first to have thought through the paradox of the death of God on the cross from the vantage point of a dialectic that embraces the indissolubility of seriousness and play. In this respect Žižek's most important interlocutor from the classical period of German Idealism is neither Schelling nor Hegel, but one to whom Žižek never refers and whom his 
critics similarly neglect: the novelist Johann Paul Friedrich Richter (17591826), known by the linguistically hybrid nom de plume Jean Paul. Reading Jean Paul alongside Žižek brings out the dialectical approach both writers take to play and seriousness, in contrast to the one-sided exaltation of play that Žižek finds in poststructuralism and in "the superego injunction to enjoy," the definitive psychic predicament of capitalist postmodernity. ${ }^{11}$

Both writers' treatment of seriousness and play unfolds in and through extended meditations on Christological motifs. For both Jean Paul and Žižek, the contradictory unity of the divine and the human in Christ models a transcendence paradoxically immanent in human subjectivity. "What is 'in you more than yourself" is as much a concern of Jean Paul's novels as of Žižek's philosophy. ${ }^{12}$ Surprisingly, it is the novelist and not the philosopher who explicitly articulates the dialectic of seriousness and play that frames both writers' engagement with the figure of Christ. Thus, reading Jean Paul in the light of Žižek's thought may help explicate what remains implicit, or even unthought, in Žižek's own method.

\section{Jean Paul through the Parallax View}

Jean Paul is an author of terminally moribund canonicity, ever being resurrected by eccentrically faithful scholars. Fittingly, his oeuvre is a rich archive for the Romantic motif of mock-death that Zižek himself practices at the end of his documentary video. Figures of mock-death and resurrection litter Jean Paul's works, as do reflections on the Trinity. Not only was Jean Paul a believer who sided with Friedrich Jacobi against the Kantian interdiction on cognitive access to the objects of religious faith, but he also plotted out in a comic mode many of the figures of the Christian imaginary, such as death, resurrection and revelation.

Jean Paul's 1805 novel Siebenkäs concerns the title character, Firmian Siebenkäs, a "lawyer for the poor" (Armenadvokat) in the small town of Kuhschnappel. A locally well-known wit with literary aspirations, Siebenkäs finds marital life with his kindly but literal-minded spouse impossible. With the unmarried Englishwoman Natalie, he seeks a new life amenable to the uncontainable humoristic aspirations that he shares both with her, an exile from the land of Laurence Sterne, and with the novel's narrator.

Jean Paul titles his novel "Flowers, Fruit and Thorns: The Life, Death and Wedding of Firmian Siebenkäs in the Imperial Market-Spot of Kuhschnappel" (Blumen, Frucht und Dornenstücke: Leben, Tod und Hochzeit des Armenadvokaten Firmian Siebenkäs im Reichsmarktflecken Kuhschnappel). The congeries of "flowers, fruit and thorns" refer to the novel's discursive hybridity, marked, as 
in Jean Paul's other novels, by digressive fireworks in hyperbolic emulation of Sterne. Yet Siebenkäs incorporates a particularly enigmatic digression, in which Firmian Siebenkäs's mock-death and new life are haunted by the death and resurrection of Christ. In the excursus, "The Speech of the Dead Christ from Atop the Cosmos, Saying That There is no God" (Die Rede des toten Christus vom Weltgebäude herab, daß kein Gott sei), Christ appears as a homeless revenant searching in vain for his Father: the agonized Christ on the cross shouting "Father, why hast thou forsaken me?" projected onto eternity. ${ }^{13}$ The excursus interrupts the novel at its midpoint in the form of a dream recounted by an anonymous narrator. Neither in plot nor narrative voice does Jean Paul integrate this vision into the lives of Siebenkäs, Lenette and Natalie.

The novel dares us to interpret the relationship between Siebenkäs's "death" and that of God as the Son. Cosmic and comic presentations of death and resurrection appear side by side in Siebenkäs, without the explicit mediation that a common narrator or integration into the plot might provide. This lack of mediation exemplifies Žižek's notion of "parallax," his version of Hegel's speculative identity of opposites. ${ }^{14}$ "Parallax" emerges in Žižek's work in response to the challenge from Kojin Karatani, who uses the term to mean a gap between two different perspectives from which no synthesis can emerge: Karatani thereby means to vindicate Kantian critique against Hegelian dialectic.

From "subjective" and "objective" reality to the Marxian categories of "production" and "exchange," Karatani sets a series of oppositions into play, insisting that only by bracketing the one can one see the other properly; his "transcendental stance" is an oscillation between such irreconcilables, in which they mutually "critique," i.e. delimit each other. ${ }^{15}$ To Žižek opposites separated by the "parallax gap" are the same element viewed within irreconcilable frames of reference, which for that reason cannot come into contact: though "closely connected, even identical in a way, they are...on the opposed sides of a Moebius strip." 16 Examples include the subjective experience of "the mind" and the "brain" studied scientifically, the waveparticle duality, and the simultaneous appearance, in early twentieth century Russia, of revolutionary avant-garde art and revolutionary socialist movements, neither of which was in position to understand the other. ${ }^{17}$

As the Hegel to Karatani's Kant, Žižek reads this apparent roadblock of antinomy as the cornerstone of dialectic. In particular, Žižek's commitment to the Hegelian "negation of the negation" informs his analysis of the crucifixion. ${ }^{18}$ His reflections on this topic form part of an extended polemic with the misunderstood Hegel at work in the formula thesis - antithesis - synthesis. Whereas this naive philosophy of reconciliation begins 
with unity and passes through negation on its way to a higher unity, Žižek sees in negation the primal fact of human existence, which can be made productive only through a further negation.

By contrast, Ludwig Feuerbach falls prey to the philosophy of reconciliation in his critique of religious alienation. To him the human being is whole before she mistakenly projects her own human traits onto that alienated self-image she calls God. ${ }^{19}$ In Žižek's eyes, the split between humanity and God is primal and can be overcome only if God Himself splits. When Christ calls out from the cross that the Father has abandoned him, the unbridgeable gap between humanity and God is reflected into God Himself. Only in this "negation of the negation" do God and humanity intersect. ${ }^{20}$ The human being is at one with God in her infinite distance from Him.

By dramatizing the dead Christ bereft of his divine Father, Jean Paul anticipates and deepens Žižek's dialectical reading of the crucifixion. The vision implicitly takes place after the resurrection - after the confirmation of Christ's godhood-yet the loneliness of this risen Christ exceeds even human loneliness. Wandering in a cosmic void, Jean Paul's Christ has lost not only God but humanity as well: looking down on the small earth in the distance, he misses the time when he shared with his fellows what the narrator later calls a "happy mortal world" (frohe vergängliche Welt). ${ }^{21}$ As Paul Fleming cogently argues, the dead Christ misses the mortal earth as the place where he and others still enjoyed the love of their divine Father; divinity appears only within the horizon of human finitude, so when cut adrift from his mortality, the (un)dead Christ also loses God.22 Where Žižek locates the merger of God and humanity in Christ's experience of death, rather than in his life as a preacher and pedagogue, Jean Paul tarries with the negative still further, discovering a further negation within the "determinate negation" of the crucifixion. Overcoming the distinction between God and humanity through his death on the cross, Christ paradoxically becomes neither God nor man. In reconciling his divinity with his humanity, he has lost both.

In the Vorschule der Ästhetik, Jean Paul's treatise on aesthetics and poetics, he defines "humorous subjectivity" with the first-person remark, "I divide my self into the finite and the infinite factor" (Ich zerteile mein Ich in den endlichen und den unendlichen Faktor). ${ }^{23}$ These two "factors" together comprise the human self just as mortal humanity and divinity comprise the being of Christ. Even if, as Žižek insists, divinity and humanity overlap when God experiences the split between the two in Himself, this experience might still look different from the distinct vantage points of God and humanity, the infinite and the finite. From the "infinite" vantage point, that of God, the story of God becoming alien to Himself appears as the Rede des toten Christus. How does one tell the same story from the finite point of view? Why not through the 
mock-death of a country lawyer who redeems his wife from the marital law, so that the "truth" made visible in his fictive death can set her free?

The juxtaposition of these two deaths in the text makes it tempting to entertain the heterodox reading of the death of God on the cross as a mockdeath. One might imagine that the Son knows that He is going to rise again, so in dying he is faking it. The pious Jean Paul would doubtless have rejected this misreading of the Bible and his novel. Rather, Siebenkäs's mock-death and "resurrection" supply within the this-worldly "finite" horizon the same experience whose "infinite factor" comes into view in the fantasy of a dead Christ speaking of his abandonment from beyond the grave. Mock-death is a way for others to approach what Jesus did on the cross: it is a form of imitatio Christi.

\section{Christian Novel, Pagan Tragedy}

In his essay "Epic and Novel," Mikhail Bakhtin connects the motif of Scheintod to the comic familiarity with which novels approach the things of the world. ${ }^{24}$ Bakhtin discerns an affinity between the novel and the popular entertainments contemporary with its rise since the early modern period. Like Hanswurst or Pulcinello, a novel's protagonists are not self-identical; their character always falls short of or exceeds their fate. Bakhtin suggests that the death most suitable to a novel's protagonist is a mock-death. ${ }^{25}$

Bakhtin recognizes the Socratic dialogue along with the Menippean satire as proto-novelistic forms marking the collapse of the tragic worldview that had reigned in Greek literature from Homer to Sophocles. ${ }^{26}$ One might add to Bakhtin's list the "romance" plays of Socrates's friend Euripides. Can there be a more overt case of non-identity than that of the abducted Iphigeneia living on in Aulis in spite of her death in Tenedos, or of Helen, who survives in Egypt the tarnished reputation of her embattled eidolon in Troy? If the concealed archetype of the tragic death is the sacrifice of the scapegoat, these Euripides plays concern the failure of sacrifice.

The subject of tragedy is the clash between the inexorable order of nature and justified human aspirations: a clash that turns individual virtues into the means of destruction for their bearers. If the novel benefits from the collapse of tragic myth, so does Christianity. In The Fragile Absolute, Žižek writes about "symbolic death": "unplugging" from the organic community ${ }^{27}$ the circle of guilt and punishment, crime and revenge, the economy of sacrifice. ${ }^{28}$ With Jesus's death, this circle is broken, leaving behind the community of believers comprising the body of Christ. ${ }^{29}$ As a member of this new movement, the individual secedes from the "substantial" community of kin or 
nation which previously anchored her, and whose rituals of sacrifice and exchange thus relinquish their ultimate validity.

Žižek rejects the ascetic interpretation of Christianity, in which the Christian establishes "inner distance" between her soul and her actions, being "in the world but not of it," as others have understood the Pauline formula $\omega \varsigma \mu \eta$. It is rather by "uncoupling" from the community and economy of sacrifice that the Christian secedes from "the world." "30

"Symbolic death" is a recurring theme in Romanticism. Witness the title of René Chateaubriand's Memoires d'Outre-Tombe, Samuel Taylor Coleridge's contest between Death-in-Life and Life-in-Death, and the aphoristic writings left behind by Jean Paul's tragicomic Icarus, the "air-sailor" (Luftschiffer) Giannozzo, after the fatal crash of his hot-air-balloon. Such performances of posthumous subjectivity explore the gap between symbolic and real death: a domain that psychoanalysis calls "between the two deaths." This gap can open in either direction, as in the case of Siebenkäs covertly outliving himself or that of Giannozzo, who lives on "symbolically" in his papers. Either way, a rupture opens between the subject and the network of meanings in which he or she is situated, the "symbolic order." Žižek recommends the realm between the two deaths as a space for revolutionary agency.

Among Giannozzo's posthumous papers is an aphorism connecting "poetry" to the apocalypse: "Like the day of judgment, poetry transforms us, in that it transfigures us, without changing us" (Gleich dem jüngsten Tage verwandelt uns die Poesie, indem sie uns verklärt, ohne uns zu verändern). ${ }^{31}$ In the

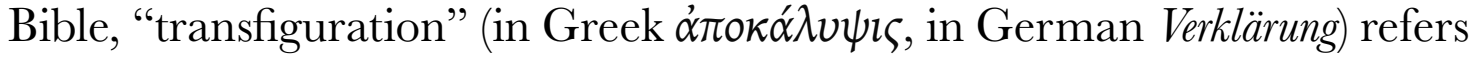
to a prophetic vision in which the divinity of Christ is vouchsafed to three of his disciples before his crucifixion. According to Giannozzo, "poetry" (Poesie) similarly "unveils" us, effecting a "transformation" in which nothing "changes."

What emerges in Poesie is the "minimal difference" revealed by what Žižek calls "enframing." 22 Žižek elaborates this technique with reference to a "theater" on the southern side of the Korean demilitarized zone in which spectators can watch the DPRK side through a window at the "stage" end. ${ }^{33}$ One of Jean Paul's characters in the novel Flegeljahre tells a nearly identical joke about a Dutchman who builds a wall behind his garden and cuts out a large window in it, so as better to enjoy the landscape beyond. ${ }^{34}$ In such a theater, in Žižek's words, "reality turns into its own appearance" (his italics). 35

Surprisingly, "appearance qua appearance" (Erscheinung, als Erscheinung) is Hegel's definition of "the supra-sensible" (das Übersinnliche), that thingin-itself or essence allegedly underlying phenomenal reality. ${ }^{36} \mathrm{It}$ is not that material reality actually conceals some pre-existing immaterial essence. 
Rather, in the framing of a phenomenon as semblance a transcendent dimension shines through, because only then does one glimpse the potential for the thing to differ from itself. If mimetic representation discloses such an immanent transcendence in human beings, in anticipation of the eschatological "transfiguration" to come, what does this tell us about human identity in the here and now?

\section{Authenticities}

On the surface, Žižek has little time for the other master of late-Marxist dialectic, Theodor W. Adorno. While the Frankfurt sage appears sparingly in Žižek's corpus, a Žižek concordance would quickly show that Adorno's much-maligned adjective "authentic" is one of Žižek's favorite words. His frequent reminders that "there is no big Other" and exhortations to the reader to "fully assume the consequences of his choice" 37 echo the existentialist insistence that we take responsibility for the values and projects that we embrace.

To a Heideggerian, the injunction to take responsibility for one's own being-in-the-world entails a responsibility for one's own death, toward which any given life is uniquely and irreparably headed. Adorno's dispute with Heidegger suggests that the latter's existentialism culminates in death. To Marxist thinkers, death is not the flowering of an inner potential but an interruption forced on us from without: to identify with it is to accept heteronomy. Implicitly, Adorno's rejection of "identity thinking" lines up with his resistance to "being toward death." ${ }^{38}$ Only in death are we self-identical. Capitalist exchange relations tend toward reification: the reduction of the living to the selfsameness of the corpse.

Adorno's lacerating critique of the "converted and unconverted philosophers of fascism" aims to expose self-identity, with all its pathos of "authenticity" (Eigentlichkeit), as a reflection of capitalist exchange relations. ${ }^{39}$ Mimesis and play-acting, tacitly recognizing the non-identity of the acting subject with that which she apes or anticipates, in Adorno's eyes signal resistance to the universe of exchange in capitalism. Where the market insists on the universal commensurability of commodities and measures human activity by the common measure of exchangeable value, artistic make-believe foregrounds incommensurability. Adorno opposes "authenticity" to "imitation, play, wanting to be something else" (Nachahmung, Spiel, Andersseinwollen), implying that such "inauthenticity" keeps alive the prospect that "something else" or "another" world is possible. ${ }^{40}$

Adorno diagnoses the existentialist glorification of authenticity as an attempt to revive "religious-authoritarian pathos" without the positive content 
of traditional religion to rely on. Paradoxically, the atheist Adorno insists that, "The self should not be spoken of as the ontological ground, but at the most theologically, in the name of its likeness to God"41 (Vom Selbstwäre nicht als dem ontologischen Grunde zu reden, sondern einzig allenfalls theologisch, im Namen der Gottesebenbildlichkeit). ${ }^{42}$ Bearing the "image and likeness" of God, the self possesses a substantial identity only in its resemblance to something it is not- whether or not that something exists.

It follows - though Adorno never draws this conclusion - that an encounter with the divine is one way for the human self to come face to face with its own otherness. Žižek extends and complicates this claim by insisting on the specifically Christian story of the encounter with God the Son as a mortal man. Having witnessed the traumatic "event" of the death of their God, Christ's followers have seceded from their previous symbolic universe. Theirs is a life "between the two deaths," freed from the symbolic order of law, sin and sacrifice, "neither Jews nor Greeks." 43

This secession from the symbolic order happens when the shattering force of the event calls forth the interpretive genius of the Apostle Paul. In Žižek's eyes, Paul accomplishes a "magical inversion" by which the trauma of Jesus's crucifixion becomes the victory on which Christianity is founded:

Saint Paul centered the whole Christian edifice precisely on the point which up to then appeared, to the disciples of Christ, as a horrifying trauma...non-integrable in their field of meaning: Christ's shameful death on the cross between two robbers. Saint Paul made of this final defeat of Christ's earthly mission...the very act of salvation: by means of his death, Christ has redeemed mankind. ${ }^{44}$

The trauma that cannot make sense within the old horizon of meaning becomes the means of opening a new horizon. So far we are on the terrain of Alain Badiou's revolutionary fidelity to the Event, and just as in Badiou's account, the early Christians serve as the model of a revolutionary community. ${ }^{45}$ Yet there is one difference: Badiou's treatment focuses not on the crucifixion, but the resurrection. Paul invents "universalism" by addressing both Jews and Greeks with the scandalous "good news" of Christ's rising, and it is this form of address that interests Badiou politically. ${ }^{46}$ Badiou's focus on the resurrection places not humanity but God "between the two death": Jesus the undead intruder, the corpse that is not a corpse.

Žižek's avoidance of the resurrection raises questions about what happens next, after "the Christian death of God." ${ }^{47}$ For Badiou, fidelity to the Event that shattered the symbolic framework of the old order of Being means acquiescence in a new order of Being that forms around that Event. In Lacanian terms, the symbolic order reasserts itself though woven around a different point. Yet Žižek insists that the Christian "unplugging" from the 
"symbolic community" does not mean the construction of a new one, but to a collective sustained by the emancipatory recognition that "there is no Big Other." 48 A few pages later, though, he concedes that "the presupposition of such a spectral/virtual substance is in a way co-substantial to being human." 49

To Žižek, the "ultimate mystery of the so-called human or social sciences" is: "how, out of the interaction of individuals, can the appearance of an 'objective order' arrive which cannot be reduced to their interaction, but is experienced by them as a substantial agency which determines their lives?"50 Lurking behind this "ultimate mystery" is the question of whether or not it is possible to live without such a reified "objective order." Žižek's formula of "faith without belief" proposes that "one can believe (have faith in) X without believing X." 51 This he presents as a formula for "the big Other, the symbolic order" which remains authoritative even once we acknowledge that it "does not exist." 52

The psychoanalytic cure that Žižek is promoting in the field of religion is precarious; it sustains the tension between the "realization that there is no big Other and the contingency of master signifiers" on the one hand, and the "patient's" inclination to create "new master signifiers" on the other. ${ }^{33}$ Though Žižek defines "liberation" as "a quasi-psychotic gesture" of "suspending the functioning" of the big Other by "assuming its nonexistence," 54 in the formula of "faith without belief" the denial of the big Other's existence helps enable that Other, the symbolic order, to function. What in one context looks like a break with the symbolic order doubles elsewhere as a key to its emergence.

Žižek wants to deny Christian faith the certainty which the sight of Christ resurrected affords to the community. In terms of a distinction we shall explore more fully later, that certainty would constitute "naïve belief" rather than "symbolic commitment." In the Rede des toten Christus the problem does not arise, since this vision of the risen Christ turns the resurrection into a prolongation of the agony of abandonment that Jesus experiences on the cross. Jean Paul accomplishes imaginatively what Zižek proposes in theory: the reduction of the resurrection to the crucifixion.

For both writers, God has His identity in the human being just as the latter has hers in God. "It is only in man, in human history, that God fully realizes Himself, that He becomes an actual living God." ${ }^{55}$ If in one account it is "man" who lands "between the two deaths" and in the other, God, that is because each has its being in the other to the extent that a complete narration of the story of their interaction must take into account the perspective of each.

Žižek reads the New Testament as a story about human becoming, 
which requires an other whose intervention displaces the human being from herself, giving her room to develop by removing the immediacy of her selfidentity: "Far from being the Highest in man, the 'divinity' is rather a kind of obstacle, a 'bone in the throat'... on account of which man cannot ever become fully MAN, self-identical. ${ }^{\prime 56}$ This obstacle alienates the human being not only existentially but narratively as well: the human story can never be exclusively his or her own. As we shall see, Jean Paul too traces this dialectic in the secular form of novelistic narrative.

\section{Mock-Death and Bildung}

The alienated self whose path Žižek traces in the medium of religion has its home in Jean Paul's time in the genre of the Bildungsroman. The novels of education that put Jean Paul on the literary map before he embarked on the narrative experiment of Siebenkäs place playful appropriations of death and resurrection at the center of characters' quests for Bildung. The model of subject-formation lurking in the background of these novels is drawn from Rousseau's Emile. In that novel the protagonist's subjectivity unfolds according to the plan set by his tutor, who is also the narrator. The poetic self bifurcates into the twin forms of the narrator and his pupil.

Both Die Unsichtbare Loge and Titan split the Romantic authorial subject, protagonist of Bildung, into two characters: in the Loge, a pupil and his tutor, in Titan, a pair of friends. In the case of Titan, the volatile poet-figure Roquairol displaces the novel's bland protagonist, Albano, from the role of Romantic subject-in-becoming. As I have argued elsewhere, Roquairol distinguishes himself from the other characters through the hyperbolic exuberance of his letters and stage performances, whose rhetorical style resembles that of no one so much as the novel's narrator. When Roquairol shoots himself on stage as a tribute to his unrequited love for a woman playing the role of his beloved in his play, he parodies Goethe's Werther by underlining the theatricality of Werther's own suicide. ${ }^{57}$

This last performance of Roquairol's is long in coming. Early in the novel, he foreshadows his coming suicide by impersonating Werther comically at a masked ball. Within the space of a single paragraph, the narrator gives conflicting accounts of what is wrong with Roquairol. On the one hand, he experienced unrequited love, "which later might have steeled him," too early to successfully sublimate it. ${ }^{58}$ On the other hand,

All motions into which love, friendship and nature lift the heart...he traversed in poems earlier than in life, as an actor and playwright before experiencing them as a man...thus when they finally appeared live in his breast, he could sensibly grasp, 
govern, kill and stuff them for the ice-chest of future memory.

...alle Bewegungen, in welche die Liebe und die Freundschaft und die Natur das Herz erheben, alle diese durchging er früher in Gedichten als im Leben, früher als Schauspieler und Theaterdichter denn als Mensch...daher, als sie endlich lebendig in seiner Brust erschienen, konnt' er besonnen sie ergreifen, regieren, ertöten und gut ausstopfen für die Eisgrube der künftigen Erinnerung. ${ }^{59}$

One way or the other, anticipation is Roquairol's problem. Roquairol "kills" and "stuffs" his passions in order to reify them for future memory. As Bakhtin declares a propos of the novel in general, "that center of activity that ponders and justifies the past is transferred to the future." ${ }^{\prime 60}$ By contrast with Homeric epic, that storehouse of memory preserving a past that contains its meaning already complete in itself, the novel orients itself onto a future that must judge the past events that the text narrates. In Bakhtin's view the future perfect is as much the implicit tense of the novel as it is for Lacanian psychoanalysis "the time of the subject," in which a subject that can only be glimpsed in process will have been. ${ }^{61}$

This meditation in the future-perfect plays out rather differently in Jean Paul's first novel, Die Unsichtbare Loge, the text with which Richter's pseudonym was born. This novel's protagonist, like Albano heir to a small princely estate, is born and raised in the aftermath of a curious agreement negotiated by his parents as the terms of their marriage. Young Gustav's future maternal grandfather, a Pietist, will let his daughter marry Gustav's future father only if the latter agrees to let their child spend the first eight years of his life in a cellar beneath a ruined building on the family estate in the sole company of a Pietist tutor whom the narrator refers to as der Genius. ${ }^{62}$ This figure tells his pupil that where they are is the earth, and that the world outside the cellar is heaven, which Gustav will enter only once he has proven himself virtuous and thus earned the right to "die." ${ }^{\text {"f }}$ At eight years of age Gustav passes the test - having learned the arts of singing, drawing and Christian piety - and ascends into paradise, leaving his tutor behind. ${ }^{64}$

The night before his "resurrection," Gustav gets a glimpse of the world he is about to enter, as his tutor opens the cellar door and lets him look out at the night sky. The narrator quickly shifts to an apostrophe to Gustav, meditating on how his first sight of the world above ground will appear to his memory "long years later," possibly after the time narrated by the rest of the novel:

Oh happy Gustav; this nocturne will remain in your soul long years later, as a sunken green island lurking under deep shadow in the sea, and will look longingly at you like a long-lost blissful eternity." 
O! Du glücklicher Gustav; dieses Nachtstück bleibt noch nach langen Jahren in deiner Seele wie eine im Meere untergesunkene grüne Insel hinter tiefen Schatten gelagert und sieht dich sehnend an wie eine längst vergangene frohe Ewigkeit." 65

It is not clear here which Gustav the narrator is addressing: is Gustav happy only as a child first gazing on the night sky, or does the reciprocal gaze of this "eternity" paradoxically form the substance of his happiness even at the unspecified time when he will have "lost" it? Either way, Jean Paul's meditations on Gustav's coming nostalgia and Roquairol's mental taxidermy establish future-perfect subjectivity as a focus of novelistic narrative, bringing Bakhtin and Lacan together by anticipation. The question of what will have become of these two characters is the key to who they are, and thereby of what each novel is doing as a narrative project. Just as Gustav owes his distinct subjectivity to the playful yet traumatic experience of "dying" at the moment he first enters the earthly world, so does Roquairol confirm his theatrical persona as he exits the world by dying on stage.

Roquairol and Gustav exemplify Samuel Taylor Coleridge's duo of "death in life and life in death." For Gustav mock-death is the entrance to a life lived in the improvised holy spirit of an invisible church. Roquairol, on the other hand, consummates with his own stage-death a death that he has been living symbolically throughout his life. Though Gustav "dies" too early and Roquairol too late, in the mock-deaths of both characters Jean Paul strives to lure that which resists assimilation, death itself, into the dialectic of earnestness and play. ${ }^{66}$

In Jean Paul, death becomes productive for Bildung through the bifurcation of the poetic subject in the multiplicity of characters furnished by the novel. Roquairol's suicide needs Albano as a witness if it is to mean something more than the death of the subject in the funhouse of reflexivity, something Jean Paul satirized in his monologue Clavis Fichtiana and polemicized with in his philosophical treatise Vorschule der Ästhetik. Remembering his "death" from the standpoint of later maturity, Gustav becomes his own witness - recounting the passing of the baton from one guiding spirit of Bildung to another.

In these early novels, Jean Paul brings the Christian scheme of death and resurrection into the midst of earthly life in service to the Romantic goal of an immanent transcendence. But in earnest? In the Vorschule der Ästhetik, he calls "poetry" or "literature" (Poesie) "the only second world in the first one," where "miraculous forms (Wundergestalten) walk about upright and blessed," "second world" being Jean Paul's term for "the world to come." 67 This earnest claim for literary mimesis echoes the fantastical claim that Gustav's childhood tutor makes for the world within the narrated content of Jean Paul's first novel. In Jean Paul's discourse "poetry" and "resurrection" come 
together, but on whose terms? To answer this question, let us return briefly to Žižek.

\section{Fetishistic Disavowals}

Early in his career, Žižek develops the Lacanian notion of "fetishistic disavowal" for political thought. This notion names the passage from "naive belief" in a magical object to "symbolic faith" in the cause that the object now signifies. ${ }^{68}$ The paradigm for this transition appears in a scene from the annals of anthropology provided by Octave Mannoni. Adults from the Hopi people in the American Southwest bring their children to a yearly festival in which a group of masked men - the people's gods, they tell the children - performs a sacred dance. At an appointed time, the men remove their masks and reveal themselves to the children as their fathers, uncles and grandfathers. Far from succumbing to disillusionment, the children are in awe of their elders, who for the duration of the ritual have become one with the gods in spirit. As Žižek puts it, the children have learned to locate the sacred in the mask itself, not in anything that it hides. The sacred mask translates into "the mystique of the institution," which, by taking the place of the belief that can no longer be sustained directly, comes to mediate between individuals in their social interactions. ${ }^{69}$ With this passage from ritual repetition to symbolic representation, "traditional authority" has been born. $^{70}$

How does this primal scene of the symbolic relate to Christianity? On the one hand, as the ideological support for authority, fetishistic disavowal is the key to what Christian revelation seeks to undermine, and Žižek finds it operative wherever an inner distance enables subjects to act toward authorities as if they were authoritative, thus confirming the existence of "the big Other," the objective order of symbolic commitments. ${ }^{71}$ On the other hand, something resembling fetishistic disavowal takes place in Christianity itself, as "naïve belief" in the physical presence of the living God gives way to a practical commitment to the community of believers - the Holy Spirit - after Jesus's death on the cross.

There is a fine line between these two transitions, and Žižek is at pains to distinguish them. At one point he writes that "the 'Holy Spirit' is the community deprived of its support in the big Other," retains the scheme of the "big Other" but turns it around: "it is humanity, not God, which is the big Other here...by dying on the cross...He provided us, Humanity, with the empty $\mathrm{S}$, Master-Signifier, and it is up to Humanity...to live up to it, to decide its meaning, to make something of 
it." ${ }^{\prime 73}$ That is, to reconstruct the symbolic order ourselves, aware that there is nothing backing it up but our own activity. This creation of what Adam Kotsko calls a "self-undermining big Other" remains paradoxical, ${ }^{74}$ and it is hard to avoid the impression that the Christian breakthrough to the Holy Spirit is as much a repetition of the initial breakthrough into the symbolic universe as its reversal. Žižek confirms this impression when he repeatedly cites G.K. Chesterton's claim that "civilization itself is...the most romantic of rebellions" and "morality...the most dark and daring of conspiracies." 75

In one of his meditations on Christ's moment of doubt on the cross, Žižek muses that "maybe, at a deeper level" the anguished Christ has taken our crippling doubt onto himself, becoming our "subject supposed NOT to believe... instead of doubting, mocking, and questioning things while believing through the Other, we can also transpose onto the Other the nagging doubt, thus regaining the ability to believe." ${ }^{\prime 76}$ While in the initial moment of fetishistic disavowal, we suspend our belief, which becomes lodged in the "mystique of the institution," in its Christian repetition we suspend our disbelief, thus regaining the ability to "believe," that is, to engage directly in our relations to others. Žižek fills out this notion of "belief" when, mobilizing Lacan's line les non-dupes errent, he states, "the true believer believes in appearances, in the magic dimension that 'shines' through an appearance." 77

"Suspension of disbelief" is Coleridge's well-known formula for immersion in literary fiction, and it was that poet's German contemporaries who established the philosophical significance of schöner Schein ("beautiful appearance"). ${ }^{78}$ Yet the Romantic author whose way of working through the problem of semblance was most compatible with Žižek's is Jean Paul. In Die Unsichtbare Loge he makes Gustav's childhood "death" and "resurrection" an occasion for "fetishistic disavowal." In a letter to his tutor "Jean Paul," the mature Gustav reflects on the sublime experience of mistaking earth for heaven as a key moment in his moral and spiritual development. ${ }^{79}$ Through first mistaking this world for the "second world," Gustav learns to relate to others as if they were specimens of resurrected humanity. Gustav's "naive belief" gives way to "symbolic faith," qualifying Gustav for membership in the category of "higher people" (hohe Menschen) nominated by the tutornarrator Jean Paul in an excursus addressing the reader. ${ }^{80}$

This league of the enlightened recalls the "invisible lodge" of the novel's title, an allusion to the notion of an "invisible church" comprising those who have risen above the rites and dogmas of folk religion to realize Christianity's spiritual core. In the eighteenth century, opposing tendencies laid claim to the term, which goes back as far as Augustine and Luther. ${ }^{81}$ The elevation of a community within a community appealed to German Pietists as well as to Freemasons, both of whom distinguished themselves from the "visible 
church" maintained by custom and authority. ${ }^{82}$ In the early 1790 's, Lessing, Herder and Kant give the term currency for Enlightenment thought, in writings roughly simultaneous with Die Unsichtbare Loge. ${ }^{83}$ Attempting to square the circle of faith and reason, Kant designates as "the church invisible" the ideal union of all subjects devoted to the moral law: the regulative ideal for any actual religious community. ${ }^{84}$

Jean Paul enhances the "invisible church" tradition politically by making his "invisible lodge" a secret society conspiring to overthrow the existing feudal order - something which does not come to fruition in the unfinished novel. Marxist critic Wolfgang Harich argues that such a plot cannot materialize, because Jean Paul knew that positively depicting such an emancipated future would be irresponsibly utopian..$^{85}$ Yet the novel also introduces a more subtle innovation into the tradition of the "invisible church." In Gustav's emergence from the cave, Jean Paul makes the revelation of an "invisible church" contingent on a deceptive mise-en-scène, which the protagonist both sees through and commits to, as if to assert that les non-dupes errent.

Like Mannoni's Hopi children, Gustav owes his spiritual initiation to a moment when the mask falls. By echoing the claims of Gustav's childhood tutor in his characterization of poetic writing in the Vorschule, Jean Paul presents the paradox of a spiritual transformation won through self-conscious fictionality, which the novel already underlines by redoubling "Jean Paul" as both the author and the character who receives Gustav's post-resurrection confession. As narrator of the Loge and theorist of the Vorschule, Jean Paul invites the reader to undergo the symbolic initiation that Gustav has already accepted. In the reader's initiation, the sacred mask is the text itself: the insubstantial poetic semblance that "transfigures us without changing us." In this way Jean Paul stages a fetishistic disavowal positioning literature itself as the "big Other," locus of symbolic commitment.

\section{Aesthetic Education}

Jean Paul's "fetishistic disavowal" challenges the Romantic-era notion of "play" as the defining human activity. In his Letters on Aesthetic Education, Friedrich Schiller sees in "play" the synthesis of the conflicting rational and sensual vocations of the human being, and declares that "man...is only fully human when playing" (der Mensch... ist nur da ganz Mensch, wo er spielt)." Yet this exaltation of play, issuing from the pre-Hegelian thesis-antithesissynthesis model of dialectic implicitly at work in Schiller's text, splits play off from seriousness in ways that unwittingly undercut the autonomy of the aesthetic. 
Schiller calls on the "play drive" to mediate between opposing forces weighing on the human being as biological organism and as subject to the moral law. ${ }^{87}$ What Kant calls "freedom," the ability to discern and abide by the moral law, Schiller considers a necessity no less onerous than the natural "necessity" that orients us toward survival and the egotistical search for pleasure. ${ }^{88}$ By naming "play" as the mediator between these two manifestations of "earnestness" Schiller unwittingly raises the question of opposition between "play" and "earnestness" as such. ${ }^{89}$

If the mutual sublation of the two forms of earnestness in aesthetic mediation is a cancellation of "earnestness," then Schiller imagines "play" overcoming "earnestness" one day in the "aesthetic state" foretold by our experience of artworks, and present in nuce in "select circles" that have already internalized aesthetic education..$^{90}$ Meanwhile, seriousness dominates elsewhere in our lives. In the prologue to Wallenstein, Schiller writes that "life is serious, while art is joyful" (Ernst ist das Leben, heiter ist die Kunst), a statement made to order for the bourgeois division between the week's work and Sunday diversions, including the theater. ${ }^{91}$

Schiller lacks a concrete vision of how play might shape social conditions rather than merely inform how subjects act within them, and he has not considered that the "law" that aesthetically educated subjects will take pleasure in executing may turn out to be mere bourgeois convention, rather than Kant's exalted moral law. In Terry Eagleton's words, Schiller's aestheticism is a formula for "hegemony," prone to appropriation by the status quo. ${ }^{92}$ Eagleton sees play in Schiller as a double-edged sword, both a utopian fantasy of a world beyond alienation and a model for integrated capitalist subjectivity. Jean Paul's poetics of play deepens this ambiguity - nowhere more clearly than in his late novel Der Komet (1825).

This novel tells the mock-messianic story of Nikolaus Marggraf, apothecary in the small town of Rom. Surrounded by a motley coterie of followers from among the small artisans and workers of the town, Marggraf inverts his name, declaring himself "Margrave (Marggraf) Nikolaus" and leading his little band into the wilderness in search of the promised land. By an imaginative short-circuit, Rom becomes Rome, the marginal community making itself capital of Christendom. Once the group has arrived at its destination, Marggraf sets up court and directs court entertainments, including a bergerie in which the "margrave" appears onstage playing a small-town apothecary. ${ }^{93}$

Thomas Wirtz proposes a Schillerian reading of Der Komet in which Marggraf cancels his alienation in an act of aesthetic play, recovering as play what was assigned to him as labor. ${ }^{94}$ This reading misses the parodic element of Marggraf's performance, which mocks the nobility's custom of picturing commoners' lives as idyllic. There is a difference between a stage 
apothecary performed by Marggraf and one performed by a professional actor, because there is a difference between playing an apothecary and actually being one, even if Marggraf humorously combines both roles in his person. While the prospect that under other social relations work might become play may fuel utopian desire, the imperative to turn work into play here and now is bourgeois ideology at its purest. In Nikolaus Marggraf, the gap between "play" and "earnestness" remains, "play" itself being subject to alienation.

\section{Minimal Differences}

Jean Paul's subtle critique of Schiller resonates in Žižek's polemics with poststructuralism. Žižek frames his arguments against the "philosophy of finitude" he considers "predominant" on the postmodern intellectual landscape, which tells us that "all we can do is accept the contingency of our existence, the basic lack of any absolute point of reference, the playfulness of our predicament." ${ }^{95}$ Yet this philosophy of playfulness turns out to be humorless, no more so than in Heidegger, its progenitor. Žižek contrasts the "utmost seriousness" of this master and his poststructuralist inheritors to the style of Kierkegaard, who "relied so much on humor precisely because he insisted on the relationship to the Absolute and rejected the limitation of finitude." $" 96$

Žižek implies that without "seriousness," there can be no "play," and Jean Paul spells this out in his response to the Jena Romantics, acolytes of an absolutized "play" in his own time. Just as "all dreaming presupposes not only a past wakefulness, but a future one as well" (jedes Träumen setzt nicht nur ein vergangenes Wachen, auch ein künftiges voraus), he writes in a passage of the Vorschule probably aimed at Friedrich Schlegel: "every act of play is...the soft twilight leading from an earnestness that has been overcome to one that is higher. One plays about seriousness, not play (Jedes Spiel ist blo $\beta$ die sanfte Dämmerung, die von einem überwundenen Ernst zu einem höheren führt. Um Ernst, nicht um Spiel, wird gespielt). ${ }^{97}$ Play is mimetic and anticipatory, remembering and foreshadowing at once. Moreover, the distinction between them will never be overcome - not even in death! When Jean Paul claims that literature foreshadows the afterlife, he describes the latter as "the future play," as if capable of imagining the resurrection only as theater:

The highest thing, that which will always escape our actuality, even the most beautiful actuality of the heart; this it supplies, and paints on the curtain of eternity the future play...that something, whose lacking bifurcates and splits our thought and intuition, this most holy thing it draws down from heaven with its enchantment... 
Gerade das Höchste, was aller unserer Wirklichkeit, auch der schönsten des Herzens ewig abgeht, das gibt sie und malt auf den Vorhang der Ewigkeit das künftige Schauspiel...Jenes Etwas, dessen Lücken unser Denken und unser Anschauen entzweiet und trennt, dieses Heiligste zieht sie durch ihre Zauberei vom Himmel näher herab... ${ }^{98}$

This "highest thing" that is always lacking uncannily resembles the "objet petit a," that contingent object in which the unsatisfiability of desire comes into focus, signaling "what is in you more than yourself." ${ }^{\prime}$ Recounting the story of an Argentine politician who escapes a mass demonstration against him by wading through the crowd wearing a mask of himself, Žižek comments that "a thing is its own best disguise." 100 The world to come appears to Jean Paul masked by its own simulacrum, as art's prophetic mimesis turns even eternity into its own appearance. If "that something" that poetic art makes visible "bifurcates and splits" our consciousness, then why should it not split as well the anticipation of redemption?

Jean Paul's views reflect a Christian anthropology in which the human being's orientation onto the beyond splits her consciousness, denying her the self-possession necessary for a merely "earnest" standpoint, even on belief itself. The political dimension of this viewpoint can best be seen in contrast to Schiller's harmonious dialectic. Writing at the time of an abortive bourgeois revolution whose emancipatory promise he hoped to resuscitate with the sponsorship of enlightened princes, Schiller ascribes the reality of social domination to the inability of human subjects freely to choose the moral law. As aesthetic pleasure renders duty palatable, the emergence of autonomous subjects pleasurably choosing moral action should enable not only aesthetically integrated subjectivity but also a socially integrated "aesthetic state." 101

Schiller's utopian project aims to transform both the individual and society such that each is attuned to the other's needs. To this end he calls on the aesthetic to heal torn subjects by enabling them to find their pleasure in acting as agents of the law. In Louis Althusser's terms, "aesthetic education" would be history's first case of a fully successful interpellation. Actual interpellation on some level always fails, leaving behind a "remainder," which Žižek identifies as "objet petit a," object-cause of desire. ${ }^{102}$ Žižek contends that the chance of a revolutionary break is to be found, not in perfecting interpellation, but in holding fast to that remainder, on account of which the subject cannot maintain her self-identity.

Here lies the import of Jean Paul and Zižek's shared fascination with effects of masking, framing, and playing oneself on stage: attempts to establish a "minimal difference," to formalize the non-coincidence of the subject with herself. Such a minimal difference separates the author of 
the Loge from the tutor-narrator who also pioneers the name "Jean Paul" in that debut performance: two fictive beings set apart by the formal gap separating a text's author (or "author-function") from its narrator. Far from creating a solipsistic hall of mirrors, Jean Paul writes himself into his oeuvre in somewhat the way that God, according to Žižek, intervenes in Creation as Christ: by stepping "into his own creation," 103 he signals its incompleteness, and his own.

Žižek's oeuvre, like Jean Paul's, comprises a heterogeneous mass of texts permeated by self-citation, in which familiar insights and anecdotes recur in substantially different contexts. In all of these interruptions and repetitions, what keeps Žižek's oeuvre from forming an ordered totality is the presence of the writing subject in the work. This formal feature of his oeuvre suits its content: Zižek seeks to reanimate a German Idealist dialectic attuned to the way meaning comes into being as a socially situated response to the traumatic lack or inconsistency constitutive of the human subject. Not content to observe from a distance how "the cunning of reason" turns human actions against their bearers' intentions - a tragic approach culminating in 'Stalinism, with its belief in History as the 'big Other' that decides on the 'objective meaning' of our deeds"-Žižek reminds us that there is no historical process that does not already include us as subjects. ${ }^{104}$ That is, as subjects with an excess, a remainder that survives the process of interpellation and disturbs the smooth functioning of the symbolic order which grants us our public identities.

Žižek invokes Christ as "the name of this excess inherent in man, man's ex-timate kernel," both the defining feature of the human and that which prevents it from attaining self-identity. Thus he interprets Pilate's ecce homo in the light of a Hegelian "infinite judgment": "man is man' indicates the non-coincidence of man with man, the properly inhuman excess which disturbs its self-identity." 105 This excess is not visible to the naked eye, any more than is the difference between a country and a map of it in 1:1 scale, in the whimsical example provided by Lewis Caroll: "A country can serve as its own map insofar as the model/map is the thing itself in its oppositional determination, that is, insofar as an invisible screen ensures that the thing is not taken to be itself." 106 This "invisible screen" is "the minimal "empty" (self-)difference... operative when a thing starts to function as a substitute for itself." 107 This is how Christ can be both humanity's substitute in its relationship with God, and God Himself among humans. He is humanity in its "oppositional determination," a man occupying the God-position. In Christ, humanity substitutes for itself, finding in itself the "primordial difference" that otherwise obtains only between humanity and God.

If Christ stands for this "primordial difference" at the heart of the human 
subject, then Jean Paul intuited rightly that humor was the only way for him as a literary author to approach Christ. Seriousness means self-identity, whereas doubling, masking, framing and self-performance are inherently comical, or uncanny. Jean Paul understood that the dialectic of the divine and human in Christ implies a dialectic of seriousness (Ernst) and play (Spiel). While a serious core is needed to sustain play, only play can make visible the enigma of minimal difference in which both Jean Paul and Žižek locate the ultimate seriousness. Play and seriousness are therefore both distinct and inseparable. Jean Paul works to elucidate their relationship both in theory and through the narrative and rhetorical resources available to the novel.

Bilkent University

\section{NOTES}

1. Taylor, Žižek!

2. Eric Santner identifies "dialectic" as "the circular/spiral path of loss and redemption," calling Hegel "master of the spiral plot structure." Santner, Hölderlin: Narrative Vigilance, 39.

3. Taylor, Žižek!

4. Žižek, Puppet and Dwarf, 101.

5. Ibid., 6.

6. Žižek and Gunjević, God in Pain, 158.

7. Žižek, Puppet and Dwarf, 3.

8. Ibid., 171.

9. Ibid., 53.

10. I owe this parallel, with some alterations, to Kotsko, Žižek and Theology, 98-9.

11. Žižek, The Fragile Absolute, 24.

12. Žižek, The Parallax Viewe, 18.

13. Jean Paul, Werke I/2, 266-71.

14. Žižek, Parallax View, 4.

15. Karatani, Transcritique, $2 \mathrm{ff}$.

16. Žižek, Parallax View, 4.

17. Ibid. 4.

18. Žižek, Less Than Nothing, 292.

19. Karl Marx \& Fredrich Engels, Werke, Band 3, 533; Žižek, Puppet and Dwarf, 171.

20. Žižek and Gunjević, God in Pain, 180.

21. Jean Paul, Werke I/2, 271. Unless otherwise stated, all translations are my own.

22. Fleming, Pleasures of Abandonment, $112 \mathrm{ff}$.

23. Jean Paul, Werke I/5, 132.

24. Bakhtin, Dialogic Imagination, 36.

25. Ibid.

26. Ibid. 22-24 ff. 
27. Žižek, On Belief, 121.

28. Žižek, Fragile Absolute, 127.

29. Žižek and Gunjević, God in Pain, 54-55.

30. Žižek, Fragile Absolute, 123 ff.

31. Jean Paul, Werke III, 997.

32. Žižek, Parallax View, 28.

33. Ibid.

34. Jean Paul, Werke II, 890.

35. Žižek, Parallax View, 28.

36. Hegel, Werke II, 119.

37. Žižek, On Belief, 4.

38. Adorno, Negative Dialektik / Jargon der Eigentlichkeit, 184, 515 ff.

39. Adorno, Minima Moralia, 174; (English), 152.

40. Ibid. 175; (English), 153.

41. Ibid. (English), 154.

42. Ibid. (German), 176.

43. Žižek, Fragile Absolute, 121.

44. Žižek, They Know Not, 29.

45. Badiou, Saint Paul, 6.

46. Ibid. $105 \mathrm{ff}$.

47. Žižek and Milbank, The Monstrosity of Christ: Paradox or Dialect., 257.

48. Žižek and Gunjević, God in Pain, 55.

49. Ibid. 59.

50. Ibid. 58.

51. Žižek, On Belief, 109.

52. Ibid., 109-110.

53. Davis, et al, Theology after Lacan, 225-6.

54. Žižek, Enjoy Your Symptom, $110 \mathrm{ft} .45$

55. Žižek, Fragile Absolute, 107.

56. Žižek, On Belief, 90.

57. Coker, "Narratives of Emergence," 401.

58. Žižek, On Belief, 90.

59. Ibid.

60. Bakhtin, Dialogic Imagination, 31.

61. Lacan, Écrits, 300; Żižek, They Know Not, 222.

62. Jean Paul, Werke I/1, 52.

63. Ibid. 57.

64. Ibid. 63. For a discussion of this episode in the context of constructions of interiority, see Coker, "Narratives of Emergence," $387 \mathrm{ff}$.

65. Jean Paul, Werke I/1, 60.

66. Among Jean Paul critics Herbert Kaiser recognizes most clearly the dynamic involved in Gustav's paradoxical death, which he calls "Gustavs's resurrection into the this-worldly" (Gustavs Auferstehung ins Diesseitige). Kaiser, Jean Paul lesen, 26.

67. Jean Paul, Werke I/5, 39.

68. Žižek, They Know Not, 247.

69. Ibid., 249.

70. Ibid., 245-9.

71. Žižek, Puppet and Dwarf, 112. 
72. Ibid, 171.

73. Ibid, 136.

74. Kotsko, Žižek and Theology, 98.

75. Žižek, Event, 92.

76. Ibid., 102.

77. Ibid., 80.

78. Samuel Taylor Coleridge, Biographia Literaria II, 6; Schiller, Werke in Drei Bänden. II, 592 and 603.

79. Jean Paul, Werke I/1, 355-60.

80. Ibid. 221-4.

81. Wallace, Church of the Living God, 54 .

82. Magee, Hegel and Hermetic, 73.

83. Irmscher... Weitstrahlsinniges" Denken, 103.

84. Kant, Religion within Boundaries, 111.

85. Harich, Fean Pauls Revolutionsdichtung, 175-6.

86. Schiller, Werke II, 555.

87. Ibid., 550.

88. Ibid. 568.

89. Ibid., 555.

90. Ibid., 601-4.

91. Schiller, Werke III, 360.

92. Eagleton, Ideology of the Aesthetic, 106-9.

93. Jean Paul, Werke I/6, 890.

94. Jean Paul, Ideen-Gewimmel, $21 \mathrm{ff}$.

95. Žižek and Gunjević, God in Pain, 181-2.

96. Ibid., 182.

97. Jean Paul, Werke I/5, 444.

98. Ibid. 447. Jadwiga Kita-Huber seeks to explain Jean Paul's weird use of the apparently plural substantive Lücken with two singular verbs, entzweiet und trennt. Noting the discrepancy between the Norbert Miller edition (used in this essay) and the earlier Eduard Berend edition, which uses the singular Lücke, Kita-Huber thinks Jean Paul may be substantivizing an otherwise unattested verb lücken, which not only designates a state of "lacking," but also, in association with the verb locken, the act of "seducing" (verfuihren) us to "look" (lugen) further. "That which 'bifurcates and splits our thought'...is grasped as something that on the one hand is lacking and/or a gap, and on the other hand...makes sight possible" (Was <<unser Denken und unser Anschauen entzweiet und trennt $>>$, wird als etwas erfasst, das einerseits fehlt bzw. eine Leerstelle ist, andererseits...das Schauen überhaupt erst ermöglicht). While Kurt Wölffel and other critics stress that poetry supplies something otherwise lacking in experience, Kita-Huber adds that the lack itself is what motivates desire. Pushing her insight further, we may suggest that for Jean Paul it is poetry which first brings this "lack" to consciousness. Fean Paul und das Buch der Bücher, $251 \mathrm{ff}$.

99. Žižek, Parallax View, 117.

100. Ibid. 28.

101. Schiller, Werke II, 601-4.

102. Žižek, Incontinence, 302-3.

103. Žižek, Less Than Nothing, 706. I owe this citation to Adrian Johnston, Adventures in Transcendental Materialism, 79.

104. Žižek, Puppet and Dwarf, 171. 
105. Ibid, 143.

106. Ibid.

107. Ibid., 141.

\section{BIBLIOGRAPHY}

Adorno, Theodor W. Minima Moralia: Reflexionen aus dem beschädigten Leben. Frankfurt am Main: Suhrkamp, 1970.

_- Minima Moralia: Reflections on a damaged life. Jephcott, E.F.N., trans. London: Verso, 2005.

—, Negative Dialektik / Fargon der Eigentlichkeit. Frankfurt: Suhrkamp, 2003. 184, 515 ff.

Alston, Wallace Jr. The Church of the Living God: A Reformed Perspective. London: Westminster John Knox Press, 2002.

Badiou, Alain. Saint Paul: la Fondation de l'universalisme. Paris: Presses Universitaires de France, 1997.

Bakhtin, M.M. The Dialogic Imagination. Translated by Caryl Emerson and Michael Holquist. Austin, TX: University of Texas Press, 1981.

Coker, William. "Narratives of Emergence: Jean Paul on the Inner Life." Eighteenth Century Fiction 21.3 (Spring 2009): 385-411.

Coleridge, Samuel Taylor. Biographia Literaria II, edited by James Engell and W. Jackson Bate. Princeton, NJ: Princeton U. Press, 1983.

Davis, Creston, Marcus Pound, and Clayton Crockett, Eds. Theology after Lacan: The Passion for the Real. Eugene, OR: Wipf and Stock, 2014.

Eagleton, Terry. The Ideology of the Aesthetic. Oxford: Basil Blackwell, 1990.

Fleming, Paul. The Pleasures of Abandonment: Jean Paul and the life of humor. Würzburg: Königshausen und Neumann. 2006.

Harich, Wolfgang. Fean Pauls Revolutionsdichtung. Hamburg: Rowohlt, 1974.

Hegel, G.W.F. Sämtliche Werke. I. Stuttgart-Bad Canstatt: Friedrich Frommann, 1964.

Irmscher, Hans-Dietrich. "Weitstrahlsinniges" Denken: Studien zu Fohann Gottfried Herder, edited by Marion Heinz and Violetta Stolz. Würzburg. Königshausen und Neumann, 2009.

Jean Paul. Ideen-Gewimmel: Texte und Aufzeichnungen aus dem unveröffentlichten Nachlaß, edited by

Thomas Wirtz and Kurt Wölfel. Frankfurt am Main: Eichborn-Verlag, 1997.

—. Sämtliche Werke. Darmstadt: Wissenschaftliche Buchgesellschaft, 2000.

Johnston, Adrian. Adventures in Transcendental Materialism. Edinburgh: Edinburgh University Press, 2014.

Kant, Immanuel. Religion within the Boundaries of Mere Reason. Translated and edited by Allen Wood and George di Giovanni. Cambridge, UK: Cambridge University Press, 1998.

Kotsko, Adam. Žižek and Theology. London: Continuum, 2008.

Kaiser, Herbert. Jean Paul lesen. Würzburg: Königshausen und Neumann, 1992.

Karatani, Kojin. Transcritique: on Kant and Marx. London: MIT Press, 2005.

Kita-Huber, Jadwiga. Jean Paul und das Buch der Bücher. Hildesheim: Ongs, 2015.

Lacan, Jacques. Ecrits. Paris: Seuil, 1966.

Magee. Glenn Alexander. Hegel and the Hermetic Tradition. London: Cornell University Press, 2001.

Santner, Eric L. Friedrich Hölderlin: Narrative Vigilance and the Poetic Imagination. London: Rutgers University Press, 1986.

Schiller, Friedrich. Werke in Drei Bänden. Leipzig: VEB Bibliographisches Institut, 1958. 
Žižek, Slavoj and Boris Gunjević. God in Pain. Cambridge, MA: MIT Press, 2009.

Žižek, Slavoj and John Milbank. The Monstrosity of Christ: Paradox or Dialect.? edited by Creston Davis. Cambridge, Mass: MIT Press., 2009.

Žižek, Slavoj. Enjoy Your Symptom! London: Routledge, 1992.

—. Event. London: Melville House, 2014.

—. For They Know Not What They Do. London: Verso, 1990.

—. Less Than Nothing. London: Verso, 2012.

—. The Incontinence of the Void. Cambridge, MA: MIT Press, 2017.

—. The Fragile Absolute. London: Verso, 2000.

—. The Parallax View. Cambridge, MA: MIT Press, 2006.

—. The Puppet and the Dwarf. Cambridge, MASS: MIT Press, 2003.

. On Belief. London: Routledge, 2001.

Žižek! Directed by Astra Taylor. London: ICA Films, 2007. DVD. 